\title{
Analisis Kesesuaian Lahan Rehabilitasi Mangrove di Kecamatan Bontoa Kabupaten Maros Provinsi Sulawesi Selatan
}

\author{
The Analyze Land Suitability of Mangrove Rehabilitation Area in District Bontoa \\ Maros, South Sulawesi
}

\author{
Amran Saru ${ }^{1 凶}$, Muh Nur Fitrah ${ }^{2}$, dan Ahmad Faizal ${ }^{1}$ \\ ${ }^{1}$ Departemen Ilmu Kelautan, Fakultas Ilmu Kelautan dan Perikanan, Universitas Hasanuddin \\ ${ }^{2}$ Pusat Penelitian dan Pengembangan Wilayah, Tata Ruang dan Informasi Spasial, Universitas Hasanuddin \\ Jln. Perintis Kemerdekaan Km 10, Makassar, 90245 \\ ${ }^{凶}$ correspondent author: amransaruprof@gmail.com
}

\begin{abstract}
Abstrak
Mangrove merupakan salah satu ekosistem pesisir yang sangat penting karena memiliki fungsi ekologis serta ekonomis bagi masyarakat pesisir. Saat ini hutan mangrove mengalami kerusakan dari tekanan yang berat akibat pertumbuhan penduduk. Untuk mengurangi kerusakan mangrove maka perlu dilakukan upaya rehabilitasi mangrove. Penelitian ini bertujuan menganalisis dan memetakan kesesuaian lahan untuk mengrove di Kecamatan Bontoa. Manfaat dari penelitian yaitu memberikan informasi tentang analisis kesesuaian lahan untuk rehabilitasi mangrove. Penelitian ini dilaksanakan pada bulan Maret 2011. Metode yang digunakan adalah metode survey lapangan dengan parameter kondisi arus, pasang surut, gelombang, suhu, salinitas, kondisi substrat dan kemiringan lereng. Data dianalisis dengan metode skoring dan diplot berdasarkan peta. Hasil penelitian menunjukkan dua kategori kesesuaian yaitu sesuai dan cukup sesuai. Untuk jenis sesuai didapatkan jenis Rhizophora spp, Avicennia spp, Sonneratia alba, S. caseolaris, Bruguiera parvilofa dan B. Xesangula. Sementara kategori cukup sesuai dari jenis B. gymnorhiza. Kondisi mangrove yang dapat direhabilitasi di Desa Ampelkale sebesar 55,375 ha, Desa Pajukuang 6,636 ha, dan Desa Bontobahari 16,011 ha.
\end{abstract}

Kata kunci: kesesuaian lahan dan rehabilitasi ekosistem mangrove

\begin{abstract}
Magrove ecosystem is one of the coastal ecosystem has a very important role, because it has a physical function, bioekologis and economical for coastal communities. Currently the mangrove suffered damage from the severe pressure due to population growth. To reduce the damage it is necessary to mangrove rehabilitation, one of the factors to consider are suitability rehabilitation. This study aims to analyze and map the suitability of mangrove rehabilitation area in District Bontoa Maros South Sulawesi. Benefit from the results of this study, expected to provide information on the analysis of land suitability for rehabilitation magrove. This research was conducted in March 2011. The method used is survey method with parameters Field current conditions, tides, waves, temperature, salinity, substrate conditions, and slope. Data analyzed by the scoring method and plotted based on the map. Results of this study showed two categories namely accordance suitability and sufficient appropriate. Categorized according to the type of Rhizophora spp, Avicennia spp, Sonneratia alba, S. caseolaris, Bruguiera parvilofa and B. Xesangula; and sufficient appropriate to B. gymnorhiza. Conditions mangrove areal extents that can be rehabilitated at each study site: Ampelkale village of 55.375 ha, 6.636 ha Pajukuang Village, and the Village of Bontobahari 16.011 Ha.
\end{abstract}

Keywords: Land suitability and rehabilitation of mangrove ecosystem

\section{Pendahuluan}

Hutan mangrove di Sulawesi Selatan diperkirakan seluas 104.030 ha. Luas mangrove berdasarkan studi baseline yang dilakukan tahun 2010 di 4 kabupaten di Sulawesi Selatan, yaitu Kabupaten Barru seluas 96,92 ha, Kabupaten Maros seluas 43,05 ha, Kabupaten Pangkep seluas 60,7 ha dan Kabupaten Takalar seluas 1.083,8 ha. Sehingga total luas hutan mangrove pada 4 kabupaten sekitar 1.284,92 ha atau sekitar 1,235\% dari luas hutan mangrove di Sulawesi 
Selatan. Komposisi jenis mangrove yang banyak ditemukan adalah jenis Avicennia spp, Rhizophora spp, Bruguiera spp, Sonneratia spp, dan beberapa mangrove ikutan seperti Acanthus ilisifolius dan Nypa fruticans (Saru, 2011).

Wilayah pesisir Kabupaten Maros yang terbentang sepanjang 31 km, terdiri dari beberapa kecamatan pada daerah pesisir diantaranya Bontoa, Lau, Maros Baru dan Marusu dimana terdapat kawasan hutan mangrove. Untuk wilayah Kecamatan Bontoa memiliki panjang garis pantai sepanjang 8,2 km. Dimana pada daerah ini memiliki luasan mangrove sekitar 45,89 ha. Terdiri dari berbagai desa yang ada di pesisir yang memiliki luasan mangrove yang berbedabeda. Desa Bonto Bahari memiliki luasan mangrove sekitar 15,71 Ha, Desa Pajukukang memiliki luasan 15,11 Ha dan Desa Ampekale 15,07. Peningkatan pemanfaatan lahan hutan magrove menyebabkan keadaan hutan mangrove semakin terdesak dan terancam kelestariannya (Dinas Perikanan, Kelautan dan Peternakan Kabupaten Maros 2010)

Kerusakan hutan mangrove yang disebabkan oleh konversi lahan menjadi areal pertambakan ikan dan udang, penebangan hutan mangrove secara liar, lemahnya pembinaan dan pengendalian, lemahnya konsistensi kebijakan pengelolaan pesisir dan mangrove, kurang tegasnya sikap instansi yang berwenang dan perbedaan persepsi antara berbagai sektor pembangunan masyarakat. Penggunaan ekosistem mangrove untuk kepentingan lain atau rusaknya mangrove memberikan dampak pada penurunan produktivitas perikanan di daerah pesisir. Menyadari akan pentingnya hutan mangrove bagi kehidupan masyarakat baik langsung maupun tidak langsung maka perlu dilakuan Analasis Kesesuaian Lahan untuk Rehabilitasi Mangrove pada wilayah pesisir Kec. Bontoa, Kab Maros, agar nantinya dapat digunakan sebagai acuan atau bahan pertimbangan dalam usaha rehabilitasi Mangrove.

\section{Bahan dan Metode}

\section{Waktu dan Tempat}

Penelitian ini dilaksanakan mulai bulan Maret sampai September 2011 yang meliputi studi literatur, penyusunan proposal, pengambilan data lapangan, analisa sampel, analisis data dan penyusunan laporan hasil penelitian. Adapun lokasi penelitian di wilayah pesisir Kecamatan Bontoa (Gambar 1). Kegiatan menganalisis dan mengolah data dilakukan di Laboratorium Inderaja dan SIG (Sistem Informasi Geografis). Sedangkan untuk analisis jenis substrat dilakukan di Laboratorium Geomorfologi dan Manajemen Pantai Jurusan Ilmu Kelautan, Fakultas Ilmu Kelautan dan Perikanan, Universitas Hasanuddin, Makassar. 


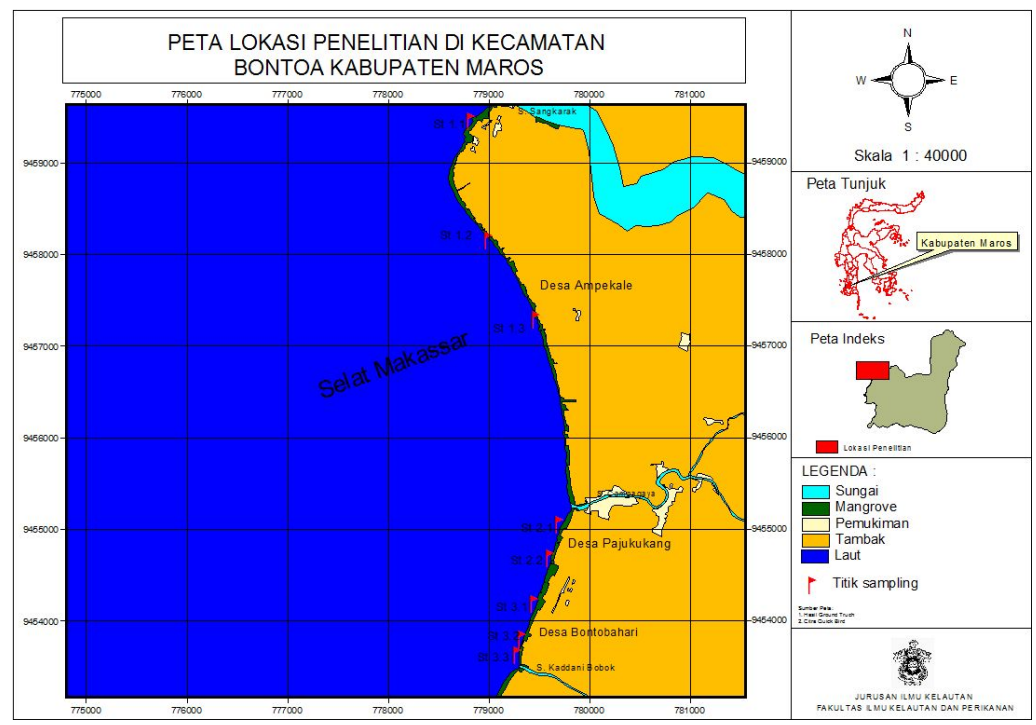

Gambar 1. Peta lokasi penelitian di Kabupaten Maros

\section{Penentuan Stasiun}

Penentuan stasiun pengamatan mengacu pada aspek ekologi ekosistem pesisir dan distribusi hutan mangrove pada masing-masing desa survei. Stasiun pengamatan terdiri atas 3 stasiun yang mewakili daerah penanaman atau rehabilitasi mangrove, yaitu: Stasiun I terletak di sepanjang pesisir Desa Ampekale, Stasiun II terletak di sepanjang pesisisr Desa Pajukukang dan Stasiun III terletak di kawasan pesisir Desa Bontobahari.

\section{Pengambilan Data}

Data yang dikumpulkan berupa data primer dan data sekunder, seperti : Arus, Pasang Surut, Gelombang diukur sesuai Suriamihardja (1998), Substrat (Sedimen) Hutabarat dan Evans (1984), Kelerengan diukur sesuai Djurdjani (1998). Untuk menentukan kelayakan suatu perairan, dilakukan pada setiap parameter sesuai dengan metode rangking pembobotan Faisal (2007) dalam Asri (2008). Selanjutnya penentuan kategori kelayakan lahan berdasarkan interval kelas dengan kategori kesesuaian: $\mathrm{X} 0=$ nilai minimal dari skala penilaian, $\mathrm{X} 1=$ hasil penjumlahan dari X0 dengan kisaran nilai antar kelas, $\mathrm{X} 2=$ hasil penjumlahan dari $\mathrm{X} 1$ dengan kisaran nilai antar kelas, $\mathrm{X} 3=$ nilai maksimum dari skala penilaian (Tabel 1).

Tabel 1. Penentuan Kategori Keayakan lahan berdasarkan interval kelas.

\begin{tabular}{llc}
\hline No & \multicolumn{1}{c}{ Interval kelas } & Kategori Kelayakan \\
\hline 1 & X0 (nilai min $)-\mathrm{X} 1(\mathrm{X} 0+\mathrm{Ci})$ & Tidak sesuai \\
2 & $\mathrm{X} 1-\mathrm{X} 2(\mathrm{X} 1+\mathrm{Ci})$ & Cukup sesuai \\
3 & $\mathrm{X} 2-\mathrm{X} 3($ nilai $\max )$ & Sesuai \\
\hline Sumber $:$ Selamat $(2002)$ &
\end{tabular}

Sumber : Selamat (2002) 


\section{Sistem penilaian dan paremeter untuk pertumbuhan mangrove}

Penilaian dan paremater untuk Pertumbuhan Mangrove jenis Rhizophora spp, Avicennia spp, Sonneratia alba (pedada bogem), S. caseolaris (padada), Bruguiera parvilofa dan B. Xesangula disajikan pada Tabel 2.

Tabel 2. Sistem penilaian dan paremater untuk pertumbuhan mangrove

\begin{tabular}{|c|c|c|c|c|c|c|c|c|c|c|c|}
\hline \multirow{3}{*}{ Rangking } & \multirow{3}{*}{ Parameter } & \multirow{3}{*}{ Bobot } & \multicolumn{9}{|c|}{ Tingkat Potensi } \\
\hline & & & \multicolumn{3}{|c|}{ S1 } & \multicolumn{3}{|c|}{$\mathrm{S} 2$} & \multicolumn{3}{|c|}{$\mathrm{N}$} \\
\hline & & & Skor & Nilai & $\begin{array}{l}\text { Paramater } \\
\text { keesuaian }\end{array}$ & Skor & Nilai & $\begin{array}{l}\text { Paramater } \\
\text { keesuaian }\end{array}$ & Skor & Nilai & $\begin{array}{l}\text { Paramater } \\
\text { keesuaian }\end{array}$ \\
\hline 1 & $\begin{array}{l}\text { Tipe Pasang } \\
\text { Surut }^{1}\end{array}$ & 0,25 & 3 & 0,75 & $\begin{array}{c}\text { Semi } \\
\text { Diurnal }\end{array}$ & 2 & 0,50 & Campuran & 1 & 0,25 & Diurnal \\
\hline 2 & $\begin{array}{l}\text { Kecepatan } \\
\text { Arus }^{1}\end{array}$ & 0,21 & 3 & 0,64 & $<0.5$ & 2 & 0,43 & $>0.5-0.7$ & 1 & 0,21 & $>0.7$ \\
\hline 3 & Gelombang $^{1}$ & 0,18 & 3 & 0,54 & $<1$ & 2 & 0,36 & $>1-2$ & 1 & 0,18 & $>2$ \\
\hline 4 & $\begin{array}{l}\text { Ukuran } \\
\text { Partikel }^{4}\end{array}$ & 0,14 & 3 & 0,43 & Halus & 2 & 0,29 & Pasir & 1 & 0,14 & Kerikil \\
\hline 5 & Sanilitas $^{3}$ & 0,11 & 3 & 0,32 & $10-30$ & 2 & 0,21 & $31-40$ & 1 & 0,11 & $>40$ \\
\hline 6 & $\mathrm{Suhu}^{2}$ & 0,07 & 3 & 0,21 & $10-30$ & 2 & 0,14 & $31-40$ & 1 & 0,07 & $>40$ \\
\hline 7 & Kelandaian $^{5}$ & 0,04 & 3 & 0,11 & Landai & 2 & 0,07 & Sedang & 1 & 0,04 & Terjal \\
\hline & Total & 1 & & 3 & & & 2 & & & 1 & \\
\hline
\end{tabular}

Selanjutnya penilaian dan paremater untuk pertumbuhan mangrove jenis B. gymnorhiza (tanjang merah) disajikan pada Tabel 3.

Tabel 3. Sistem Penilaian dan paremater untuk Pertumbuhan Mangrove

\begin{tabular}{|c|c|c|c|c|c|c|c|c|c|c|c|}
\hline \multirow{3}{*}{ Ra ng ki ng } & \multirow{3}{*}{ Parameter } & \multirow{3}{*}{ Bobot } & \multicolumn{9}{|c|}{ Tingkat Potensi } \\
\hline & & & \multicolumn{3}{|c|}{ S1 } & \multicolumn{3}{|c|}{$\mathrm{S} 2$} & \multicolumn{3}{|c|}{$\mathrm{N}$} \\
\hline & & & Skor & Nilai & $\begin{array}{l}\text { Paramater } \\
\text { keesuaian }\end{array}$ & Skor & Nilai & $\begin{array}{l}\text { Paramater } \\
\text { keesuaian }\end{array}$ & Skor & Nilai & $\begin{array}{l}\text { Paramater } \\
\text { keesuaian }\end{array}$ \\
\hline 1 & $\begin{array}{l}\text { Tipe Pasang } \\
\text { Surut }^{1}\end{array}$ & 0,25 & 3 & 0,75 & $\begin{array}{c}\text { Semi } \\
\text { Diurnal }\end{array}$ & 2 & 0,50 & Campuran & 1 & 0,25 & Diurnal \\
\hline 2 & $\begin{array}{l}\text { Kecepatan } \\
\text { Arus }^{1}\end{array}$ & 0,21 & 3 & 0,64 & $<0.5$ & 2 & 0,43 & $>0.5-0.7$ & 1 & 0,21 & $>0.7$ \\
\hline 3 & Gelombang $^{1}$ & 0,18 & 3 & 0,54 & $<1$ & 2 & 0,36 & $>1-2$ & 1 & 0,18 & $>2$ \\
\hline 4 & $\begin{array}{l}\text { Ukuran } \\
\text { Partikel }^{4}\end{array}$ & 0,14 & 3 & 0,43 & Kerikil & 2 & 0,29 & Halus & 1 & 0,14 & Pasir \\
\hline 5 & Sanilitas $^{3}$ & 0,11 & 3 & 0,32 & $10-30$ & 2 & 0,21 & $31-40$ & 1 & 0,11 & $>40$ \\
\hline 6 & $\mathrm{Suhu}^{2}$ & 0,07 & 3 & 0,21 & $10-30$ & 2 & 0,14 & $31-40$ & 1 & 0,07 & $>40$ \\
\hline 7 & Kelandaian $^{5}$ & 0,04 & 3 & 0,11 & Landai & 2 & 0,07 & Sedang & 1 & 0,04 & Terjal \\
\hline \multicolumn{2}{|c|}{ Total } & 1 & & 3 & & & 2 & & & 1 & \\
\hline
\end{tabular}

Sumber : 1) Suramiharja (1998), 2) Mohamaze (2008), 3)Hardwinanto (2008), 4)Graha dalam Erwin (2005), 5) Djurdjani (1998)

Nilai skoring setiap parameter didapatkan dengan melakukan penilaian dengan menggunakan formulasi sesuai Faisal (2007) dalam Asri (2008), sehingga diperoleh penentuan kategori kelayakan berdasarkan Interval Kelas sebagai berikut: S1= Sesuai, dengan nilai 78 100\%, S2= Cukup Sesuai, dengan nilai $55-78 \%$, dan N= Tidak Sesuai, dengan nilai $<55 \%$. 


\section{Hasil dan Pembahasan}

\section{Gambaran Umum}

Kecamatan Bontoa merupakan salah satu dari 14 kecamatan yang berada di Kabupaten Maros. Secara geografis Kecamatan Bontoa terletak pada posisi 119³0'36"-119039'00" BT dan 4'53'24"-457'36" LS. Luas wilayah Kecamatan Bontoa secara keseluruhan 93,52 km². Letak Geografis kecamatan Bontoa berbatasan langsung dengan: sebalah Utara Kabupaten Pangkep, sebelah Selatan Kecamatan Lau, sebelah Timur Kecamatan Lau dan Kecamatan Bantimurung, sebelah Barat Selat Makassar. Daerah penelitian merupakan daerah yang berhadapan langsung dengan perairan terbuka dan terhadap pengaruh dinamika laut Selat Makassar. Faktor oseanografi dan morfologi sangat berperan terhadap berlangsungnya dinamika pantai serta proses sedimentasi sepanjang pantai sehingga sangat rentan terhadap abrasi pantai. Pada daerah Pesisir Bontoa terdapat pemanfaatan lahan sebagai daerah tambak dan pemukiman. Kelandaian yang datar pesisir Bontoa didominasi oleh sedimen halus sehingga memungkinkan untuk pertumbuhan mangrove.

Bontoa memiliki panjang garis pantai $8,2 \mathrm{~km}$. Daerah ini memiliki luasan mangrove sekitar 45,89 ha, terdiri dari berbagai desa yang ada di pesisir yang memiliki luasan mangrove seperti: Desa Bonto Bahari memiliki luasan mangrove sekitar 15,71 Ha, Desa Pajukukang memiliki luasan 15,11 ha dan Desa Ampekale 15,07 ha. Kecamatan Bontoa mempunyai jarak tempuh $\pm 10 \mathrm{~km}$ dari ibukota kecamatan ke ibukota kabupaten. Secara administrasi Kecamatan Bontoa terbagi atas 9 desa dengan luas 93,52 km² (Tabel 4). Empat dari kesembilan wilayah desa tersebut berada di kawasan pesisir, diantaranya Desa Pajukukang, Desa Tumpabiring, Desa Ampekale, dan Desa Bonto Bahari .

Tabel 4. Luas Desa/Kelurahan di Kecamatan Bontoa.

\begin{tabular}{|c|c|c|}
\hline No & Desa/Kelurahan & Luas $\left(\mathrm{Km}^{2}\right)$ \\
\hline 1 & Ampekale & 15,07 \\
\hline 2 & Bonto Bahari & 15,71 \\
\hline 3 & Bontoa & 2,91 \\
\hline 4 & Bonto lempangan & 12,59 \\
\hline 5 & Minasa upa & 8,60 \\
\hline 6 & Pajukukang & 15,11 \\
\hline 7 & Salenrang & 9,60 \\
\hline 8 & Tunikamaseang & 6.24 \\
\hline 9 & Tupabiring & 7,69 \\
\hline \multicolumn{2}{|r|}{ Jumlah } & 93,52 \\
\hline
\end{tabular}

Sumber : Dinas Perikanan, Kelautan dan Peternakan Kabupaetn Maros (2010)

Pajukukang memiliki luas wilayah $15.11 \mathrm{~km}^{2}$ dengan 3 dusun terbagi dari 21 Rukun Tetangga dan 3 Rukun Warga. Secara umum Desa Pajukukang memiliki jumlah penduduk 
3.551 orang dengan 788 kepala keluarga. Desa Tumpabiring memiliki luas wilayah $7.69 \mathrm{~km}^{2}$ dan 4 dusun yang terbagi atas 20 Rukun Tetangga dan 4 Rukun Warga. Secara umum Desa Tumpabiring memiliki jumlah penduduk 2.198 orang dengan 497 kepala keluarga. Desa Ampekale memiliki luas wilayah $15.07 \mathrm{~km}^{2}$, memiliki 4 dusun terbagi atas 12 Rukun Tetangga dan 4 Rukun Warga, secara umum Desa Ampekale memiliki jumlah penduduk 2.547 orang dengan 573 kepala keluarga. Desa Bontobahari memiliki luas wilayah $15.71 \mathrm{~km}^{2}$, memiliki 3 dusun yang terbagi atas 11 Rukun Tetangga dan 3 Rukun Warga. Secara umum Bontobahari memiliki jumlah penduduk 1.467 orang dengan 338 kepala keluarga.

\section{Kondisi Oseanografi}

Arus adalah gerakan air yang menyebabkan terjadinya perpindahan massa air secara horisontal. Arus merupakan pergerakan massa air laut yang diakibatkan oleh adanya tiupan angin yang berhembus di atas permukaan air laut atau karena perbedaan densitas dalam air laut, atau dapat juga disebabkan oleh gerakan gelombang yang panjang atau disebabkan oleh pasang surut. Hasil pengukuran arus di lapangan menunjukkan bahwa kecepatan arus berkisar antara 0,01 hingga $0,08 \mathrm{~m} / \mathrm{dtk}$ (Tabel 5) dan merupakan arus susur pantai yang dibangkitkan oleh pergerakan angin, ombak pecah dan pasang surut. Hal ini didukung pendapat Lukiyanto (1996) bahwa kecepatan dan arah arus bisa disebabkan oleh angin yang berhembus di permukaan laut. Arus yang didapatkan tergolong arus yang lemah sehingga memungkinkan partikel-partikel sedimen yang berukuran halus dapat terendapkan dengan cepat.

Tabel 5. Hasil pengukuran Kecepatan Arus.

\begin{tabular}{|c|c|c|c|c|c|c|}
\hline stasiun & Substasiun & $\mathrm{V}(\mathrm{m} / \mathrm{dtk})$ & $\operatorname{Arah}\left(^{0}\right)$ & $\begin{array}{c}\text { Jam } \\
\text { Pengukuran }\end{array}$ & Keterangan & $\begin{array}{l}\text { Rata-rata } \\
\text { V (m/dtk) }\end{array}$ \\
\hline \multirow{3}{*}{ I } & 1 & 0,01 & 45 & 13.40 & Menjelang & \multirow{3}{*}{0,03} \\
\hline & 2 & 0,01 & 130 & 14.13 & Pasang & \\
\hline & 3 & 0,05 & 140 & 14.36 & & \\
\hline \multirow{2}{*}{ II } & 1 & 0,06 & 140 & 15.22 & Menjelang & \multirow{2}{*}{0,07} \\
\hline & 2 & 0,08 & 139 & 15.46 & pasang & \\
\hline \multirow{3}{*}{ III } & 1 & 0,02 & 90 & 16.11 & Menjelang & \multirow{3}{*}{0,03} \\
\hline & 2 & 0,04 & 55 & 16.37 & pasang & \\
\hline & 3 & 0,03 & 132 & 17.06 & & \\
\hline
\end{tabular}

Kecepatan arus yang tergolong lemah ini memungkinkan partikel-partikel sedimen yang berukuran halus pembentuk substrat, dapat terendapkan dengan cepat dan cocok untuk pertumbuhan mangrove. Nilai ini termasuk sangat sesuai untuk mangrove. Hal ini didukung pendapat Suriamihardja et al. (1998) bahwa kecepatan arus $<0.5 \mathrm{~m} / \mathrm{dtk}$ sangat layak bagi persyaratan pertumbuhan mangrove. Hasil analisis gelombang diperoleh bahwa tinggi 
gelombang signifikan pada lokasi penelitian berkisar 0,19-0,07 $\mathrm{m}$ dengan nilai rata-rata 0,13 $\mathrm{m}$. Periode gelombang rata-rata $(\mathrm{T})$ berkisar 2.52-6.31 detik (Tabel 6).

Tabel 6. Hasil pengukuran Gelombang

\begin{tabular}{cccccc}
\hline stasiun & Substasiun & T (detik) & H1/3 (m) & Waktu Pengukuran & $\begin{array}{c}\text { Rata-rata } \\
\text { H1/3 (m) }\end{array}$ \\
\hline \multirow{2}{*}{ I } & 1 & 6.31 & 0,08 & 13.40 & \\
& 2 & 4.52 & 0,07 & 14.13 & 0,08 \\
\hline \multirow{2}{*}{ II } & 3 & 3.29 & 0,08 & 14.36 & 0,19 \\
& 1 & 3.11 & 0,19 & 15.22 & 0,12 \\
\multirow{2}{*}{ III } & 2 & 2.52 & 0,18 & 15.46 & 0,13 \\
& 1 & 3.23 & 0,13 & 16.11 & 16.37 \\
\hline
\end{tabular}

Tinggi gelombang yang terukur pada lokasi penelitian tergolong rendah yaitu dibawah 1 meter, sehingga memungkinkan untuk pertumbuhan dan tegaknya anakan mangrove. Seperti yang di kemukakan oleh Suriamihardja et al. (1998) bahwa gelombang pantai yang sebagian besar dipengaruhi angin merupakan penyebab penting abrasi dan suspensi sedimen. Pada pantai berpasir dan lumpur, gelombang dapat membawa partikel-partikel pasir dan sedimen laut. Partikel besar atau kasar akan mengendap kemudian terakumulasi membentuk pantai berpasir. Hal ini memungkinkan mangrove akan tunbuh (Noor et al. 1999 dan Tim Revisi Strategi Pengelolaan Mangrove di Indonesia 2003).

Hasil pengukuran suhu tiap stasiun berkisar antara $32-30^{\circ} \mathrm{C}$, dengan rata-rata $31,33^{\circ} \mathrm{C}$. Hal ini disebabkan karna pengukuran suhu pada setiap stasiun dilakukan pada siang hari dan berada pada kondisi yang cerah. Kisaran suhu yang diperoleh pada lokasi penelitian tersebut masih berada pada kriteria yang sangat sesuai untuk pertumbuhan mangrove. Muhamaze (2008) mengatakan bahwa suhu rata-rata untuk pertumbuhan mangrove maksimal $32^{\circ} \mathrm{C}$ pada siang hari dan minimal $23^{\circ} \mathrm{C}$ pada malam hari. Pendapat lain juga dikatakan oleh Bengen (2004) dan Kusmana (2003) bahwa hutan mangrove tumbuh optimal pada suhu tropik di atas $20^{\circ} \mathrm{C}$ (Tabel 7).

Secara umum kisaran salinitas yang didapatkan selama penelitian untuk setiap stasiun pengamatan memperlihatkan nilai yang hampir seragam yaitu antara 25-27\%o dengan rata-rata 25,61\%o (Tabel 7). Kondisi yang cerah menyebabkan peningkatan suhu perairan pada saat siang hari hingga sore hari, hal ini telihat dengan terjadinya peningkatan salinitas pada beberapa stasiun yang diukur. Dengan meningkatnya suhu perairan pada siang hingga sore hari menyebabkan salinitas relatif tinggi atau mengalami peningkatan. Hal ini didukung pendapat 
Nybakken (1992) dan Nontji (2002) yang menyatakan bahwa perbedaan salinitas terjadi karena perbedaan penguapan dan presipitasi.

Tabel 7. Hasil pengukuran Suhu

\begin{tabular}{|c|c|c|c|c|c|c|c|}
\hline Stasiun & Substasiun & suhu ${ }^{0} \mathrm{C}$ & $\begin{array}{c}\text { Rata-rata } \\
{ }^{0} \mathrm{C}\end{array}$ & $\begin{array}{c}\text { Sanilitas } \\
(\%)\end{array}$ & $\begin{array}{c}\text { Rata-rata } \\
(\%)\end{array}$ & $\begin{array}{c}\text { Kelandaian } \\
\left({ }^{\circ}\right)\end{array}$ & Rata-rata $\left({ }^{\circ}\right)$ \\
\hline \multirow{3}{*}{ I } & 1 & 30 & \multirow{3}{*}{31,3} & 25 & & 0.97 & \multirow{3}{*}{0,57} \\
\hline & 2 & 32 & & 25 & 25 & 1,43 & \\
\hline & 3 & 32 & & 25 & & 0,28 & \\
\hline \multirow{2}{*}{ II } & 1 & 31 & \multirow{2}{*}{31} & 25 & \multirow{2}{*}{25,5} & 0,40 & \multirow{2}{*}{0,54} \\
\hline & 2 & 31 & & 26 & & 0,68 & \\
\hline \multirow{3}{*}{ III } & 1 & 31 & \multirow{3}{*}{31,7} & 27 & & 0,28 & \multirow{3}{*}{0,38} \\
\hline & 2 & 32 & & 26 & 26,3 & 0,05 & \\
\hline & 3 & 32 & & 26 & & 0,80 & \\
\hline & Rata-rata & & 31,33 & & 25,61 & & 0,50 \\
\hline
\end{tabular}

Menurut Bengen (2004) bahwa durasi pasang surut berpengaruh besar terhadap perubahan salinitas pada areal mangrove. Salinitas air menjadi sangat tinggi pada saat pasang naik dan menurun selama pasang surut. Hasil analisa pengukuran salinitas yang diperoleh sangat sesuai untuk pertumbuhan mangrove. Hal ini sesuai dengan pernyataan Lugo (1980 dalam Tim Revisi Strategi Pengelolaan Mangrove di Indonesia 2003) bahwa sanilitas air dan sanilitas tanah rembesan merupakan faktor penting dalam pertumbuhan, daya tahan, dan zonasi mangrove. Tumbuhan mangrove tumbuh subur di daerah estuaria dengan sanilitas 10-30 ppt. Hal ini didukung pula oleh pendapat Hardwinarto (2008) yang mengatakan bahwa ekosistem mangrove dapat tumbuh dengan salinitas 10-30\%.

Berdasarkan hasil pengamatan dan pengukuran, lokasi penelitian memiliki tipe pasang surut diurnal tide (tipe harian tunggal) dimana terjadi satu kali pasang dan satu kali surut selama 24 jam. Tinggi muka air maksimum adalah $159 \mathrm{~cm}$ dan tinggi air minimum $90 \mathrm{~cm}$, Sehingga diketahui nilai Duduk Tengah Sementara (DTS) adalah sebesar 128,95 cm. Berdasarkan data yang didapatkan pada tahun 2010 pada buku pasang surut dimana daerah Makassar yang dijadikan sebagai tempat yang mewakili lokasi penelitian, dengan menggunakan Metode Admiralti dengan perhitungan 360 jam didapatkan tipe pasang surut campuaran condong diurnal, sesuai dengan dengan pendapat Dahuri (1996).

Durasi pasang surut berpengaruh besar terhadap perubahan salinitas pada areal mangrove. Salinitas air menjadi sangat tinggi pada saat pasang naik, dan menurun selama pasang surut. Perubahan tingkat salinitas pada saat pasang merupakan salah satu faktor yang membatasi distribusi spesies mangrove. Pada areal yang selalu terendam satu atau dua kali sehari selama \pm 20 hari sebulan hanya Rhizophora mucronata yang tumbuh baik (Bengen 2004). Bruguiera spp. dan Xylocarpus spp. jarang mendominasi daerah yang sering tergenang. Namun hal ini 
tidak menutup kemungkinan untuk jenis lain dapat tumbuh walaupun pada kondisi pasang surut seperti itu. Menurut Bengen (2000) bahwa Avicennia marina, Bogem (Sonneratia) dan Tancang (Bruguiera gymnorrhiza) dapat tumbuh pada daerah frekuensi genangan pasang 30-40 kali/bulan.

Ukuran partikel suatu pantai dipengaruhi oleh faktor oseanografi yaitu besarnya gelombang, arus dan keberadaan sungai yang mensuplai sedimen. Gelombang yang relatif tenang dan arus yang lemah menyebabkan pengendapan partikel sedimen yang berukuran kecil terlebih dahulu, kemudian disusul oleh sedimen yang berukuran besar atau kasar sehingga memungkinkan distribusi partikel sediman dapat bervariasi. Persentase ukuran sedimen terbesar yang ditemukan pada masing-masing stasiun adalah pasir halus yang tercampur dengan sisa-sisa cangkang gastropoda. Cangkang ini mengandung zat kapur yang dapat membantu proses pertumbuhan mangrove. Macnae (1968) mengatakan bahwa kehadiran bahan kapur sangat penting artinya bagi proses pertumbuhan mangrove, terutama untuk daerah yang mempunyai tingkat salinitas yang tinggi.

Hampir semua stasiun dibentuk oleh pasir yang halus. Adanya substrat sedimen yang halus karena daerah tersebut relatif tenang dengan kecepatan arus yang lemah dan gelombang yang relatif tenang. Kondisi ini mengakibatkan terjadinya pengendapan partikel yang lebih halus karena ketidakmampuan ombak dan arus membawa partikel sedimen ke laut lepas. Keadaan ini menyebabkan terbentuknya pantai yang luas, datar, dangkal dan sedimen dasar yang halus. Kondisi substrat tersebut memungkinkan untuk Avicennia marina dapat tumbuh. Macnae (1968) mengemukakan bahwa Avicennia marina merupakan jenis yang dapat tumbuh pada berbagai tipe tanah, dari lumpur sampai pasir berbatu dan sebagai tumbuhan pioner yang tumbuh di daerah pasir.

Selain jenis Avicennia dapat tumbuh juga jenis Rhizophora, Sonneratia dan Bruguiera. Bengen (2004) menyatakan bahwa Bakau (Rhizophora) dapat tumbuh dengan baik pada substrat yang berlumpur dan dapat mentoleransi substrat lumpur berpasir, Sonneratia dapat tumbuh baik pada lokasi bersubstrat lumpur atau lumpur berpasir dari pinggir pantai ke arah darat dan Bruguiera pada tanah yang lebih keras yang terletak ke arah darat dari garis pantai.

Pada pengukuran langsung dimana kelandaian didapatkan dengan menentukan satu titik tertentu (sesuai dengan topografi dasar perairan) dengan mengukur kedalaman dan jarak secara tegak lurus dengan garis pantai, maka didapatkan kelandaian untuk masing-masing stasiun (Tabel 7). Topografi pantai merupakan faktor penting yang mempengaruhi karateristik struktur mangrove khususnya komposisi spesies, distribusi spesies dan ukuran serta luas hutan mangrove. Oleh karena itu semakin datar pantai dan semakin besar pasang surut, maka semakin 
lebar hutan mangrove yang akan tumbuh (Anonim 2003). Kondisi kelandaian di lokasi penelitian sangat sesuai untuk pertumbuhan mangrove, dimana kelandaian tersebut lebih berpengaruh terhadap terjadinya mintakat tumbuhan. Kondisi kelandaian seperti itu memungkinkan areal yang tergenang cukup luas sebagai dasar pembagian mintakat atau tipe asosiasi tumbuhan hutan mangrove (Macnae 1968).

\section{Kesesuain Lahan Rehabilitasi Mangrove}

Pelaksanaan penanaman mangrove, sebaiknya perlu mengetahui dan memahami lebih dahulu tentang karakteristik pertumbuhan dan penyebaran mangrove dan beberapa faktor fisik penunjang. Usaha penanaman mangrove suatu daerah membutuhkan standar yang dapat menggambarkan suatu daerah tersebut layak atau tidak untuk ditanami mangrove. Kriteria oseanografi (ombak, salinitas, pasang surut, arus) dan morfologi pantai (kemiringan dan substrat penyusun pantai) dapat dijadikan sebagai acuan dalam penentuan kriteria kesesuaian suatu daerah untuk ditanami mangrove. Hasil analisis faktor pembatas pertumbuhan mangrove menunjukkan kriteria sesuai untuk semua stasiun untuk jenis Rhizophora spp, Avicennia spp, Sonneratia alba, S. Caseolaris, Bruguiera parvilofa dan B. Xesangula (Tabel 8 dan Gambar 2).

Tabel 8. Hasil pengukuran Kesesuaian Rhizophora spp, Avicennia spp, Sonneratia alba (pedada bogem), S. caseolaris (padada) Bruguiera parvilofa dan B. Xesangula.

\begin{tabular}{cccc}
\hline Stasiun & Substasiun & Persentase & keterangan \\
\hline \multirow{2}{*}{ I } & 1 & 83,33 & \\
& 2 & 81,00 & sesuai \\
& 3 & 81,00 & \\
\hline \multirow{2}{*}{ II } & 1 & 81,00 & sesuai \\
& 2 & 81,00 & \multirow{2}{*}{ sesuai } \\
\multirow{2}{*}{ III } & 1 & 81,00 & \\
& 2 & 81,00 & \\
\hline
\end{tabular}

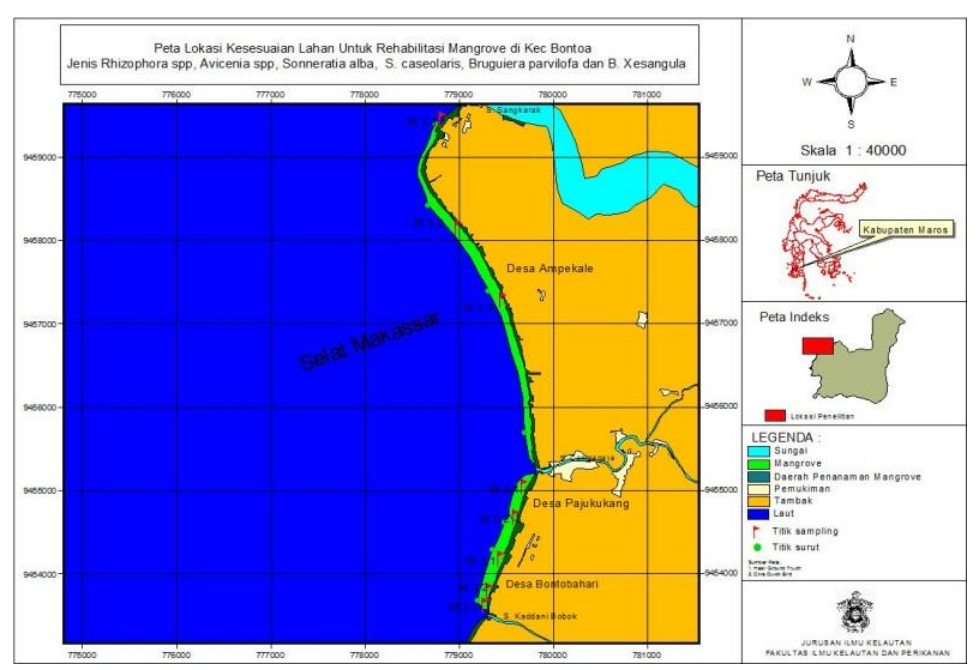

Gambar 2. Peta titik lokasi kesesuaian rehabilitasi mangrove di Kecamatan Bontoa jenis Rhizophora spp, Avicennia spp, Sonneratia alba, S. caseolaris, Bruguiera parvilofa dan B. Xesangula. 
Kecepatan arus di lokasi penelitian berkisar antara 0,01-0,08 m/det sehingga diberi skor 3 (sesuai). Hal ini didukung oleh Suriamihardja (1998) bahwa kecepatan arus $<0.5 \mathrm{~m} / \mathrm{dtk}$ sangat layak bagi persyaratan pertumbuhan mangrove. Tinggi gelombang signifikan pada lokasi penelitian berkisar 0,08-0,19m dengan rata-ratakan 0,13 $\mathrm{m}$ sehingga di beri skor 3 (sesuai). Kisaran suhu $30-32^{\circ} \mathrm{C}$ diberi skor 2 (Cukup Sesuai), sedangkan salinitas dengan kisaran 2527\% diberi skor 3 (sesuai). Ukuran partikel yang diperoleh diberi skor 3 (Sesuai) karena dari hasil analisis diperoleh ukuran partikel sedimen yang halus cocok untuk pertumbuhan mangrove jenis Avicennia yang tumbuh di daerah berlumpur/pasir halus. Bengen (2004) menyatakan bahwa pada daerah yang paling dekat dengan laut dengan substrat berpasir halus sering dijumpai Avicennia. Sedangkan Rhizophora dapat tumbuh dengan baik pada tanah yang berlumpur dan lumpur berpasir. Hal ini didukung oleh kemampuan adaptasi yang tinggi dari pohon mangrove. Bengen (2004) mengatakan bahwa pohon mangrove mampu beradaptasi terhadap kadar oksigen rendah, kadar garam tinggi, tanah yang kurang stabil dan adanya pasang-surut. Kelandaian diberikan skor 3 (sangat sesuai) karena perairan pada pesisir Kecamatan Bontoa berkategori landai dengan nilai kelandaian berkisar $0,05^{\circ}-1,43^{\circ}$ dan membentuk hamparan luas yang sangat sesuai untuk daerah pertumbuhan mangrove. Selanjutnya persyaratan kesesuaian untuk pertumbuhan mangrove dilihat dengan jumlah skor yang diperoleh dimana untuk daerah yang kurang sesuai untuk mangrove mempunyai kisaran nilai skor $<55 \%$, daerah yang cukup sesuai dengan kisaran skor antara 55-78\% dan daerah yang paling sesuai dengan kisaran skor $78-100 \%$.

Berdasarkan kriteria yang telah ditetapkan dibandingkan dengan hasil yang didapatkan di lapangan maka pada Desa Ampekale, Pajukuang dan Bontobahari didapatkan hasil sesuai dan cukup sesuai untuk daerah penanaman magrove (Tabel 8, Tabel 9, Gambar 2 dan Gambar 3). Adapun yang menjadi faktor pembatas pertumbuhan mangrove pada lokasi tersebut adalah tipe pantai terbuka. Kondisi ini memungkinkan ombak menghantam pantai tanpa adanya penghalang yang dapat membelokkan arah dan meredam energi ombak. Hal ini sangat berpengaruh terhadap anakan mangrove yang belum menancapkan akarnya dengan kuat. Namun hal tersebut dapat di antisipasi dengan pemberian Alat Pemecah Ombak (APO) pada lokasi penanaman mangrove. Penanaman mangrove merupakan hal yang mendesak melihat pada beberapa daerah pantai sepanjang Desa Ampekale, Pajukuang dan Bontobahari telah mengalami kemunduran garis pantai dan areal tambak yang sudah dekat dengan garis pantai. 
Tabel 9. Hasil pengukuran Kesesuaian B. gymnorhiza (tanjang merah)

\begin{tabular}{cccc}
\hline Stasiun & Substasiun & Persentase & Keterangan \\
\hline \multirow{2}{*}{ I } & 1 & 78,67 & \\
& 2 & 76,33 & Cukup sesuai \\
& 3 & 76,33 & \\
\hline \multirow{2}{*}{ II } & 1 & 76,33 & \multirow{2}{*}{ Cukup sesuai } \\
\hline \multirow{2}{*}{ III } & 2 & 76,33 & \multirow{2}{*}{ Cukup sesuai } \\
& 1 & 76,33 & \\
\hline
\end{tabular}

Mangrove yang didapatkan pada setiap stasiun di Kecamatan Bontoa terdiri dari beberapa jenis, antara lain Rhizophora, Avicennia, Sonneratia dan Bruguiera, namun yang dominan adalah Rhizophora dan Avicennia. Menurut Bengen (2004) bahwa daerah yang paling dekat dengan laut dengan substrat berpasir sering dijumpai Avicennia yang berasosiasi dengan Sonneratia. Sedangkan Rhizophora dapat tumbuh dengan baik pada tanah yang berlumpur dan tanah lumpur berpasir.

Sesuai data kondisi mangrove di Kecamatan Bontoa didapatkan dua kondisi yaitu sesuai dan cukup sesuai dimana kondisi yang sesuai didapatkan dari jenis Rhizophora spp, Avicennia spp, Sonneratia alba (pedada bogem), S. caseolaris (padada), Bruguiera parvilofa dan B. Xesangula dan cukup sesuai dari jenis B. gymnorhiza (tanjang merah). Kondisi mangrove yang dapat direhabilitasi di Desa Ampekale yaitu 55,375 Ha, Desa Pajukuang 6,636 Ha, dan Desa Bonto Bahari 16,011 Ha dari jenis Rhizophora spp, Avicennia spp, Sonneratia alba (pedada bogem), S. caseolaris (padada), Bruguiera parvilofa dan B. Xesangula. Hasil pengolahan sistem informasi geografis memberikan informasi bahwa luas daerah yang dapat dijadikan lokasi rehabilitasi secara keseluruhan yaitu seluas 78,022 ha.

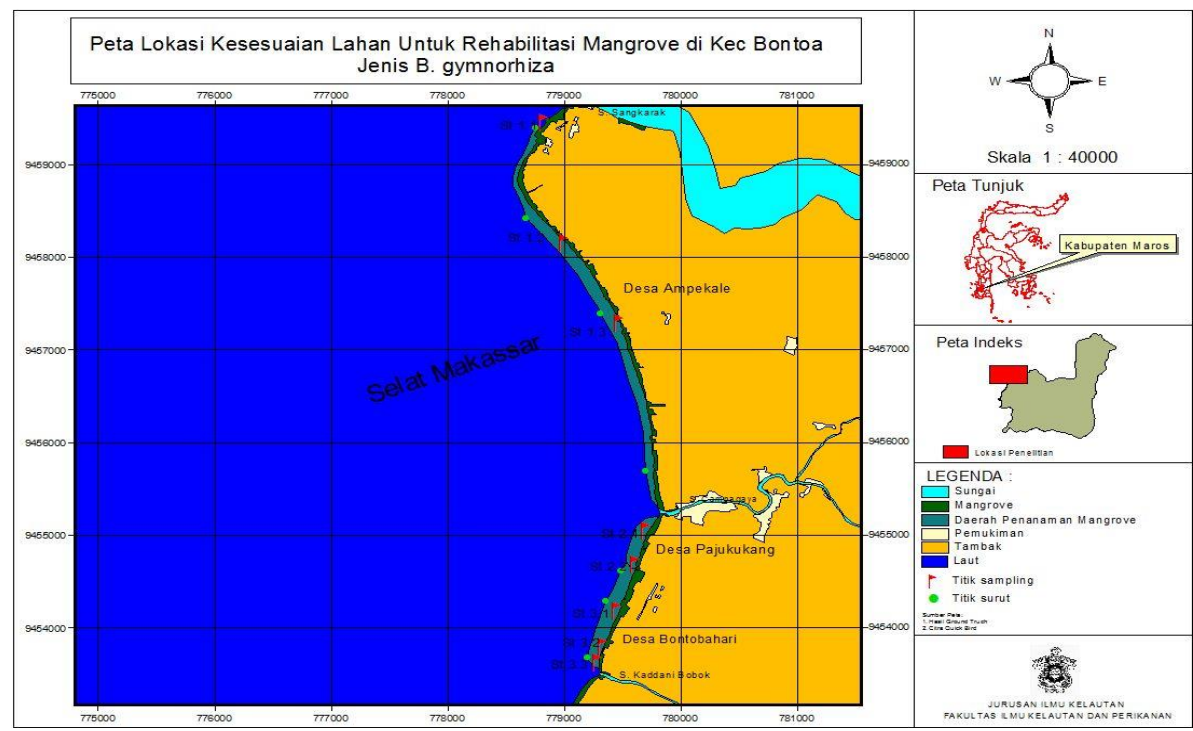

Gambar 3. Peta titik lokasi kesesuaian rehabilitasi mangrove di Kecamatan. Bontoa Jenis B. gymnorhiza (tanjang merah). 


\section{Simpulan}

Berdasarkan hasil penelitian dapat ditarik kesimpulan bahwa:

1. Kesesuaian lahan untuk rehabilitasi mangrove diperoleh 2 kategori yaitu kategori sesuai dengan nilai kesesuaian 100 - 81,00\% pada stasiun 1 dan 2. Sedang kategori cukup sesuai dengan nilai $76.33 \%$ pada stasiun 3 .

2. Luas daerah yang dapat di rehabilitasi mangrove pada kawasan pesisir pada lokasi penelitian sekitar 78,022 Ha.

\section{Daftar Pustaka}

Anonim. 2003. Strategi Nasional Pengelolaan Mangrove di Indonesia. Buku II Mangrove di Indonesia (Draft Revisi) Departemen Pendidikan Nasional. Jakarta.

Asri N. 2008. Studi Kesesuaian Lahan Unt ${ }^{\circ} u k$ Penanaman Mangrove Ditinjau Dari Kondisi Oseanografi Di Muara Sungai Pangkajene Kabupaten Pangkep. Skripsi. Program Studi Ilmu Kelautan dan Perikanan, Universitas Hasanuddin. Makassar.

Bengen DG. 2004. Sinopsis: Ekosistem dan Sumberdaya Alam Pesisir dan Laut serta Prinsip Pengelolaanya. Pusat Kajian Sumberdaya Pesisir dan Lautan. Institut Pertanian Bogor. Bogor.

Bengen DG. 2004. Pedoman Teknis. Pengenalan dan Pengelolaan Ekosistem Mangrove. PKSPL-IPB. Bogor

Dahuri R, Rais J. Ginting SP dan Sitepu MJ. 1996. Pengelolaan Sumberdaya Wilayah Pesisir dan Lautan Secara Terpadu. PT. Pradya Paramita. Jakarta.

Dinas Perikanan, Kelautan dan Peternakan Kabupaten Maros. 2010. Laporan Statistik Pesisir dan Pulau-Pulau Kecil Kabupaten Maros 2009-2010. Maros.

Djurdjani. 1998. Konsep Pemetaan. PUSPICS- Fakultas Geografi UGM. Yogyakarta

Erwin. 2005. Studi Kesesuaian Lahan Untuk Penanaman Mangrove Ditinjau Dari Kondisi Fisika Oseanografi Dan Morfologi Pantai Pada Desa Sanjai - Pasi Marannu, Kab. Sinjai. Skripsi. Program Studi Ilmu Kelautan dan Perikanan, Universitas Hasanuddin. Makassar.

Hutabarat S dan Evans SM. 1984. Pengantar Oseanografi. Universitas Indonesia Press. Jakarta.

Hardwinarto S. 2008. Faktor Penopang Keberhasilan Penanaman Mangrove. http://www.pmdmahakam.org [Akses 12 januari 2011].

Kusmana C. 2003. Teknik Rehabilitasi Mangrove. Fakultas Kehutanan, Institut Pertanian Bogor. Bogor.

Lukiyanto. 1996. Studi Laju Sedimentasi di Kawasan Muara Sungai Jeneberang, Kotamadya Ujung pandang. Program Studi Ilmu dan Teknologi Kelautan, Universitas Hasanuddin. Ujung Pandang.

Noor YR, Khazali M, Suryadiputra. 1999. Panduan Mengenai Hutan Mangrove di Indonesia. Ditjen PKA. Jakarta.

Nontji A. 2002. Laut Nusantara. Djambatan Lembaga Oseanologi Nasional-LIPI. Jakarta.

Nybakken JW. 1992. Biologi Laut. Suatu Pendekatan Ekologis. Gramedia. Jakarta. 
MacNae W. 1968. A General Account of the Fauna and Flora of Mangrove Swamps and Forests in the Indo-West-Pacific Region. Adv. Mar. Biol., 6: 73-270.

Muhamaze. 2008. Introduction to Mangrove Ecosystem (Mengenal Ekosistem Mangrove). http://www.google.com. [Akses 3 januari 2011]

Saru A. 2011. The Analysis Model of Continuitas Mangrove Ecosystem in Estuary Pangkajene Pangkep Regency. Seminar Nasional Perikanan VII UGM. Yogyakarta.

Selamat MB. 2002. Penuntun Praktikum Sistem Informasi Geografis. Jurusan Ilmu Kelautan Fakultas Ilmu Kelautan dan Perikanan. Universitas Hasanuddin. Makassar.

Suriamihardja DA, Sakka dan Massinai A. 1998. Studi Of Siwa Oceanographic Condition. Collaborative Enviromental Project in Indonesia University Consortium on The Environment. Center for Environmental Study. Hasanuddin University. Makassar.

Tim Revisi Strategi Pengelolaan Mangrove di Indonesia. 2003. Strategi Pengelolaan Magrove di Indonesia. Buku II Mangrove di Indonesia. Edisi Revisi 2003. 